\title{
Pesticide Exposures Induce Male-Mediated Reproductive Toxicity: A Review
}

\author{
Nur Afizah Yusoff ${ }^{1}$, Siti Balkis Budin ${ }^{1} \&$ Izatus Shima Taib ${ }^{1}$ \\ ${ }^{1}$ Programme of Biomedical Science, School of Diagnostic and Applied Health Sciences, Faculty of Health \\ Sciences, Universiti Kebangsaan Malaysia, Kuala Lumpur, Malaysia \\ Correspondence: Izatus Shima Taib, Programme of Biomedical Science, School of Diagnostic and Applied \\ Health Sciences, Faculty of Health Sciences, Universiti Kebangsaan Malaysia, Jalan Raja Muda Aziz, Kuala \\ Lumpur 50300, Malaysia. Tel: 60-126-510-202. Email: izatusshima@ukm.edu.my
}

Received: October 3, 2017

doi:10.5539/jas.v9n13p122

Accepted: December 18, 2017

Online Published: December 31, 2017

URL: https://doi.org/10.5539/jas.v9n13p122

The research is financed by Universiti Kebangsaan Malaysia, Malaysia via an internal grant (GGPM-2016-084).

\begin{abstract}
Infertility remains a continuing globally problem wherever couples worldwide were infertile as much as 42 million in 1990 and keep projecting to 48.5 million in 2010. Male-mediated infertility becomes one of the numerous concerns due to pesticide especially sperm quality as revealed with raising number of animal and human studies in latter-day among researchers. Pesticides have been used since the early days as pest control in agriculture, as vector controls in malaria and dengue as well as subject to much regulation. The reproductive system might be affected with some negative effects from pesticides that lead to interference with the male hormonal function. Polyunsaturated fatty acid (PUFA) content in the sperm cell membrane makes it become highly susceptible towards reactive oxygen species (ROS), thus leading to sperm damage. Besides known genetic and environmental factors, research during the last two decades has highlight on several mechanisms and their association with male infertility. The male germ line undergoes extensive epigenetic modifications throughout fetal to adult life hence vulnerable to environmental factors that may influence fertility. The present literature will help in understanding the mechanisms of pesticide in inducing male-mediated reproductive toxicity.
\end{abstract}

Keywords: epigenetic remodelling, male reproductive, oxidative stress, pesticides, sperm damage

\section{Introduction}

The desire to own children is widespread among people across the world. Infertility has been an issue globally whereas women have always been the symbol of fertility (Verma \& Baniya, 2016). For men, infertility frequently becomes a private heartache. According to Zegers-Hochschild et al. (2009), if couples, following one year or more of regular unprotected sexual intercourse still fail to obtain a clinical pregnancy, they can be said to experience infertility. The most cases of childlessness that occur are reported to be as much as $50 \%$ of infertile men as the culprit (WHO, 2014). In accordance with Agarwal et al. (2015), at least 30 million of men are infertile around the world. When sperms are restricted in number or function such as sperm concentration, motility and morphology in at least one sample of two sperm analyses, obtained 1 and 4 weeks apart, infertility problems can happen among male (Brugh \& Lipshultz, 2004).

Humans and other mammalian species are unique in their different ways of continuing their species, perhaps human would be more than in any other species. The completion of reproduction process is indicated in which the offspring development is fully accomplished (Worthman, 2003). Abnormalities of a male genome may lead to reproductive toxicity. DNA damage towards the sperm itself occurs due to an error in epigenetic modification such as DNA methylation, histone modification and chromatin remodelling (Anderson et al., 2014) as well as from excessive ROS production (Agarwal et al., 2014) that lead to miscarriage and anomalies in the offspring. Furthermore, endocrine disruption might reduce testosterone level that important for spermatogenesis and secondary sexual characteristic, hence affecting the sexual behaviour. Increasing testosterone levels showing that 
males are sexually receptive and ready for mating (Auyeung et al., 2013). Attraction, motivation and performance are some components of sexual behaviour in males and females (McGinnis \& Pfaff, 2012). Conversely, low testosterone level might reduce mating and fertility performance or make the male infertile.

Thus, it is the right time while considering these negative effects in offspring, male reproductive toxicity should certainly be approached from completely different perspectives as well as exposure in ahead of time in life (Bonde, 2010). A capitalism that happens in promptly developing world increase incidence of individuals that continuously exposed to varied environmental pollutants. Some of which are industrial waste, pesticides and polluted air thus lead to infertility (Eleršek \& Filipič, 2011). Silent Spring written by Rachel Carson in 1962, provided the impetus for tighter control of the extensive use of pesticides for the environment particularly birds as well as for human well-being. The book led to the national ban on DDT and other pesticides as consequences from some huge changes regarding pesticides in the US national policy (Carson, 1962). Administration of pesticides through several routes such as oral, dermal and inhalation will affect germline cells by causing DNA double-strand breaks and later might alter the offspring (Bal et al., 2012; Piña-Guzmán et al., 2006; Rignell-Hydbom et al., 2005; Taib et al., 2014). Hence, this review will only focus on the mechanisms and the evidence of pesticides induced male-mediated reproductive toxicity.

\section{Male-Mediated Developmental Toxicity}

Developmental toxicity has been described as the occurrence of undesirable effects on the developing organism in which the abnormality outcomes may be noticed at any stage in the lifetime of the organisms. These undesirable effects could be a consequence of any teratogens exposure involving either one or all the following period which are: before conception which only involves the parents, during prenatal development (gestational) period and/or postnatal period until the reproductive organs matured (U.S. EPA, 1991). Spontaneous abortion or miscarriage, as well as major and minor anomalies, are the end-point of developmental toxicity (Tantibanchachai, 2014). Spontaneous abortion is defined as a pregnancy that typically ends naturally (not induced) during the first 7 to 28 weeks of gestation and occurs at lower rates in most developed countries (Vorvick \& Storck, 2009). Physical or mental disabilities are the consequences of functional or structural abnormalities existing before birth or at birth known as birth defects or congenital anomalies. The main cause of death for infant have been noticed and indicated including several types of birth defects, ranging from mild to fatal during the first years of life (Mostafalou \& Abdollahi, 2013). Proposed mechanisms for such defects include transmission of chemicals directly or indirectly from the father result in transmissible genetic changes (mutations) to the conceptus via seminal fluid and contamination of the mother through the placenta (Wolff et al., 2011). Mechanisms of developmental toxicity involve the epigenetic modifications and genetic mutations as shown in the previous review article by Anderson et al. (2014).

\subsection{Epigenetic Modifications}

Male infertility is a complicated problem where not merely the genes, but additionally the epigenetic factors play essential role in producing offspring. For the past 6 decades, human genetic research has centered on DNA as the heritable molecule that holds details about phenotype from the parent to the offspring (Daxinger \& Whitelaw, 2012). Epigenetics is explained as heritable changes in gene expression or cellular phenotype, which happen without changes to the underlying DNA sequence mitotically and meiotically (Aaron et al., 2007). Production of sperm cells into mature spermatozoon during differentiation process can be attained through proper DNA epigenetic modifications. DNA methylation, histone modifications and chromatin remodelling are the main epigenetic mechanisms which involve gene expression regulation as outlined by Lestari and Rizki (2016). Correlation can be seen in DNA hypomethylation with gene expression while hypermethylation with gene silencing. An important process during early embryogenesis namely reprogramming of genome is influenced by DNA methylation and histone modifications (Rivera \& Ross, 2013).

\subsubsection{DNA Methylation}

Mammalian cells, unique organisms experienced almost entire reprogramming of DNA methylation arrangement during sperm development. Proper DNA methylation is essential for embryo development. Transcriptional silencing, gene expression and regulation, genomic imprinting and X-chromosome inactivation are associated with DNA methylation (Jones \& Liang, 2009; Kaneda et al., 2004). Cytosine-phosphate-guanine dinucleotides (CpGs) which contain 5-carbon position of cytosine is the site where methylation occurs specifically via the action of the DNA methyltransferases (DNMT) family of proteins. They are responsible for both the initiation of methylation and subsequent maintenance of methylation marks (Portela \& Esteller, 2010). Examples of DNMTs including DNMT1, DNMT3a and DNMT3b. De novo methyltransferases such as DNMT3a and DNMT3b, favoured by aiming unmethylated CpGs to start methylation by catalysing the modification at m5C. DNA 
methylation patterns can be copied from parental to daughter strands through DNMT1 that primarily identifying and methylating hemimethylated CpGs during DNA replication concurrent with its function as a maintenance methyltransferase. DNMTs can function cooperatively to methylated DNA (Jin et al., 2011).

Increasing risk of fertilisation failure, congenital abnormalities, dysfunction in embryogenesis, perinatal mortality, preterm birth and low birth weight have previously been linked with numerous human disorders due to an error in DNA methylation (Albertini, 2014; Chen et al, 2015; Komiya et al. 2015; Cheng et al., 2014; Katib et al., 2014). According to Guerrero-Bosagna et al. (2012) sperm becomes eternally reprogrammed to produce an aberrant epigenome in the embryo itself including cells and tissues derived from that embryo as a result to error changes in DNA methylation profile. Regulating epigenetic modifications involving the activity of enzymes and DNA methylation somehow have been noticed to be altered, thanks to environmental exposures.

\subsubsection{Histone Modification and Chromatin Remodelling}

Besides, mitosis and spermatogenesis are undeniably crucial in organism life in which histone modifications play role in that cellular processes. Condensed heterochromatic or open euchromatic formation is established with the help of this modification. A globular domain and histone tail, amino-terminal extensions make histones. Their compositions are rich in lysine and arginine (basic proteins) located in the nuclei of eukaryotic cells and induces packaging of DNA within lysosomes (Güneş \& Kulaç, 2013). Residue contents in histone tails can be post-translationally modified (PTMs) by acetylation, methylation, phosphorylation, sumoylation and ubiquitylation. These PTMs modify chromatin structure thus enabling the underlying gene to be activated or inhibited. Current research work has shown DNA repair, replication, stemness and alteration in cell state are influenced as well by histone core modifications. In addition, histone modifications are directly regulating transcription (Lawrence et al., 2016).

A successful spermiogenesis required extensive chromatin remodelling to occur. In this process, sperm-specific basic proteins, initially transition proteins and eventually, protamine will substitute almost all the nucleosomal histones that are required for normal sperm development (Rousseaux et al., 2008). Histone-to-protamine chromatin remodelling process happens perfectly in the presence of a master regulator, namely chromodomain helicase DNA binding protein 5 (Chd5) throughout spermiogenesis (Li et al., 2014). Spermiogenesis is a process to produce matured spermatozoa which able to move from haploid round spermatids by completing a remarkable series of events (O'Donnell, 2014). When making a comparison, it is noted that nuclei of sperm wild-type sperm with larger amounts of protamine contents are more resistant to chemical disruption (Cho et al., 2001). Additionally, the whole structure of the sperm including chromatin packing, organization and shape of acrosome might be affected with protamine reduction (Cho et al., 2003).

\subsection{Genetic Damage}

Changes in the DNA germ line is one of the genetic mechanisms of male reproductive toxicity in which the sperm may carry either lesion such as an anomaly in the number of chromosomes or after fertilisation may be changed into a chromosomal abnormality and mutation such as DNA adducts, breaks in DNA backbone and labile site. The chromosomal abnormality is associated with male infertility which includes both numerical (Klinefelter syndrome) and structural (translocations and inversions) chromosomal aberrations (Harton \& Tempest, 2012). Other genetic factors involved may be endocrine disorders of genetic origin, imprinting disorders, mitochondrial DNA (mtDNA) mutations, multifactorial disorders as well as Y chromosome deletions. According to Shamsi et al. (2011), approximately $10 \%$ genes in the genome are associated to spermatogenesis. The Y chromosome contains 7 deletions intervals whereby interval 5 and 6 regions are vital for spermatogenesis. One of the most indicative pathogenic defects in male infertility involving sperm count is related to microdeletions on the long arm of the $\mathrm{Y}$ chromosome.

The methylenetetrahydrofolate reductase (MTHFR) is necessary for DNA synthesis and methylation which has a key function during spermatogenesis in addition to folate metabolism (Ucar et al., 2015). All complete genetic information transmission to the offspring may be disrupted if there is a mutation in the MTHFR gene located on chromosome 1 in combination with an error of methylation of the nucleotides in the germ cells. This gene also presents two familiar polymorphisms involving nucleotides A1298C and C677T. The consequent reduction in enzyme activity and exchanging of alanine for valine in the MTHFR protein occur because of changing $\mathrm{C}$ for $\mathrm{T}$ at position 677 (Gava et al., 2011).

\section{Pesticide Induces Male-Mediated Reproductive Toxicity}

In recent times, researchers have proposed that semen quality has been diminished over the past many decades worldwide (Geoffroy-Siraudin et al., 2012; Haimov-Kochman et al., 2012). The reproductive system involves 
dramatic cycles of tissue growth and degeneration. The spermatogenesis is no exception to this generalised phenomenon which involves mitosis, meiosis, cellular differentiation of spermatogonia into mature spermatozoa and apoptosis (Hunter et al., 2012). Additionally, an entire hormonal stimulation from the hypothalamus and pituitary gland are required for spermatogenesis as well as the perfect function of the testes (Gabrielsen \& Tanrikut, 2016). A potential hazard makes the male reproductive system as a target because of the continued presence of germ cell that runs proliferation process and its complex endocrine system (Couse, 2008). Pesticides constitute a wide group of chemicals used in agriculture to boost food production by controlling disease vectors and eliminating undesired insects (Annabi et al., 2015). They are the general term for insecticides, rodenticides, herbicides and fungicides.

Based on their chemical nature, classified into organochlorines (OCs), organophosphorus (OPs) carbamates, synthetic pyrethroid, microbial insecticide and insect growth regulators (D'Souza, 2017). Among pesticides, OPs compounds are more than 100 widely used in agricultural chemicals (Suratman, Edwards, \& Babina, 2015). This popularity is largely contributed to their favourable characteristics such as biodegradable and short persistence compared to the OC pesticides (Chen et al., 2010). They are sprayed over crops or soils, causing residues to be found in surface and ground waters, fruits, vegetables and in drinking water (Yao et al., 2001). The main detrimental health effects are difficulty in breathing, cancer, effects on the immune system, headaches, irritation of skin and mucous membranes, skin disorders, psychological or neurological and reproductive effects. The manifestation of these effects depends on the type of pesticide, level and duration of exposure (Bretveld et al., 2006). Besides the neurotoxic effects, these pesticides have been reported involve in male-mediated reproductive toxicity via several mechanisms.

\subsection{Mechanisms of Pesticides Induced Male-Mediated Reproductive Toxicity}

\subsubsection{Endocrine Disruption}

Male reproductive system potential depends on the normal function of the hypothalamic-pituitary-gonadal (HPG) axis. Hypothalamus, pituitary gland and the germ cells contained in the testes are the contents of HPG axis. When reaching puberty, gonadotropin-releasing hormone $(\mathrm{GnRH})$, will be secreted into the blood circulation and stimulated anterior pituitary gland to secrete follicle stimulating hormone (FSH) and luteinizing hormone (LH) (Tortora \& Derrickson, 2012). This hormone secretion occurs as result of interaction between GnRH and gonadotroph cell located in the pituitary via binding of G-GnRH (Couse, 2008). Later, LH will stimulate a Leydig cell to secrete testosterone hormone from cholesterol synthesis in testis and then be used in spermatogenesis process (Foster \& Gray, 2008), differentiation and development of accessory organs, maintaining libido and secondary sexual characteristic (Zarrouf et al., 2009).

Meanwhile, androgen receptor (AR) can be found in testicular Sertoli cells where it ensures a continuation of proper spermatogenesis (Wang et al., 2009). The AR can be activated by binding of androgen such as testosterone and dihydrotestosterone (DHT). Activated AR will release heat shock protein (HSP) 70 and HSP90 into nucleus cell to activate mRNA transcription that leads to the production of a protein having an androgenic effect. HSPs are molecular chaperones that play a crucial function in the folding of misfolded proteins and in the regulation of cellular signals and transcriptional networks (Richter, Haslbeck, \& Buchner, 2010). Gene expression and hormone-regulated cell signalling pathways are easily being interfered by some environmental toxicants. This is because of the toxicants agonist or antagonist act as ligands to both steroidal and non-steroidal hormones in nuclear and membrane receptors (Zoeller et al., 2012). A defect in testosterone production will impair spermatogenesis particularly in sperm maturation and sexual behaviour such as mating process.

OP can cause disturbances with the endocrine system, which finally result in infertility. Generally, OP acts by inhibiting the synthesis of hormones or the action of neurotransmitters and cause abnormalities of homeostasis of this system. OP will alter or disrupt steroid hormone activity through the action of hormones that bind to receptors of the estrogen, androgen and thyroid hormones. In addition, OP can also interfere with the process of steroidogenesis by distressing the activity of aromatase and $5 \alpha$-reductase (Kitamura et al., 2010). Previous research showed that Chlorpyrifos at dose $9.0 \mathrm{mg} / \mathrm{kg}$ which was given orally for 70 days in male rats have reduced the absolute and relative weight of prostate gland and seminal vesicle, motility, viability and testosterone. The treated male was being observed for their ability in mating the normal female rats where the results showed low mating and fertility indices (El-Mazoudy et al., 2011). According to the researchers, Chlorpyrifos knew as the estrogenic agent that acts by catalysing androgen and estrogen production through P450 aromatase stimulation hence disrupting the regulation of steroid hormone biosynthesis by testis (Maqbool et al., 2015). Besides, Chlorpyrifos-ethyl which was given orally at various doses such as 3.5, 5.25 and 10.5 $\mathrm{mg} / \mathrm{kg}$ have been reported to give the same effects towards male rats which also due to the alterations in the male 
sex hormones, testosterone (Kenfack et al., 2015). Al-Saeed (2016) reported that oral administration of Diazonin causes infertility in male rats by decreasing the sperm quality while affecting number of litter size and testosterone level.

Besides causing direct effect towards sperm maturation, testosterone also contributes to the behaviour changes and sexual function of men (Nobre, 2014). Leydig cells of the testes secrete testosterone which essential for male sexual behaviour in nearly all vertebrate species. According to Hull and Dominguez (2007), $5 \alpha$-reductase will convert testosterone to DHT while other effects of testosterone are mediated through its aromatisation to oestradiol in target cells. Increasing testosterone level showing that males are sexually receptive and ready for mating as well as function in sexual interest and associated sexual arousability (Bancroft, 2005). Mating and fertility indices were reduced, in which one of the main causes for this could be the possible decrease in testosterone level together with unfavourable effects on libido (Farag et al., 2012). Decreasing in the relative weights of ventral prostate and testes, sperm motility and concentration, cholesterol and protein level in the serum and testes, the activity of prostatic acid phosphatase as well as fertility, gestation, litter size and parturition indices have been reported in rats treated with Dimethoate (Ngoula et al., 2014). Furthermore, there was study disclosed that exposure of rats to the subchronic administration of Methomyl magnificently decreased the fertility index, weight of testes and accessory organs, serum testosterone level as well as sperm count and motility. The incomplete arrest of spermatogenesis due to decreased in testosterone hormone contributes to all the abnormalities seen in the male rats (Shalaby et al., 2010).

\subsubsection{Oxidative Stress}

Increasing of reactive oxygen species (ROS), biochemical changes and commotion of spermatogenesis process observed in germ cells, Sertoli cells and Leydig cells indicated the occurrence of male reproductive organs damage (Couse, 2008). Increased ROS can cause oxidative damage (Lukaszewicz-Hussain, 2010) in the testis and epididymis which eventually damage the germ cells and spermatozoa (Sabeti et al., 2016). Oxidative damage occurs due to an imbalance between the production of ROS and antioxidant including enzymatic and non-enzymatic (Birben et al., 2012). A collection of a wide array of radicals which represented by ROS including hydroxyl ion, nitric oxide, lipid peroxyl, peroxyl, superoxide ion and thiyl as well as non-radical molecules for instance hydrogen peroxide, hypochloric acid, lipid peroxide, ozone and singlet oxygen (Bansal \& Bilaspuri, 2011). Glutathione reductase, glutathione peroxidase and superoxide dismutase are examples of enzymatic antioxidants while glutathione, vitamin $\mathrm{E}$, vitamin $\mathrm{C}$ and carotenoid are examples of non-enzymatic antioxidants (Mora-Esteves \& Shin, 2013).

Metabolism of cytochrome P450, monooxygenases result in ROS generation by catalysing oxidation in the substrate of OP with the addition of one atom of oxygen by electron transport pathway (Chambers et al., 2001). Taib et al. (2014) reported that sperm DNA damage occurs in male rat given $20 \mathrm{mg} / \mathrm{kg}$ Fenitrothion orally for 28 days. ROS attack carbohydrate, lipid, protein and DNA hence altering enzymatic systems, producing irreparable alterations, causing cell death and eventually lead to a decline in sperm parameters associated with male infertility (Agarwal et al., 2014). According to Das, Shaik, and Jamil (2007), phosphorus moiety in the OPs seems to be a good substrate for nucleophilic attack leading to phosphorylation of DNA which is an example of sperm DNA damage. Apoptosis and sperm DNA fragmentation were seen in male rats given Imidacloprid orally where the overwhelming production of ROS over antioxidant is the reason for these damages (Bal et al., 2012). Methyl-Parathion, a potent alkylating agent has been recognized able to change sperm chromatin condensation that leads to DNA damage where this damage may cause risk to the offspring. Furthermore, the author also suggested that this OP acts directly on the structure of sperm chromatin in mice that were given single dose through intraperitoneal injection (Piña-Guzmán et al., 2006).

\subsubsection{Genetic Damage}

A sperm is basically a package of streamlined genetic information. Increasing the sperm cell abnormalities specifically DNA damage were reported in several cases either human exposed to Polychlorinated biphenyls (Rignell-Hydbom et al., 2005) also in animal studies exposed to Methamidophos Methyl-Parathion (Piña-Guzmán et al., 2006), Imidacloprid (Bal et al., 2012) and Fenitrothion (Taib et al., 2014). Spermatogenesis is essential for the production of offspring whereby it is regulated by an estimation of more than 2300 genes (Tamowski et al., 2010). An irrevocable partial or complete spermatogenic arrest can occur as a result of genetic aberrations (Shamsi et al., 2011). Besides, result from a study by Salvadori et al. (1988) shown that structural chromosome aberrations of spermatocytes when multiple repeated exposures of Malathion were given to mice. A high percentage of accumulated genetic defect leads to increase the incidence of transmitted heritable error and chromosomal abnormalities of paternal origin in mice. These are influenced by differential DNA repair 
mechanism of post-meiotic male germ cells and later affecting zygotic metaphases in mitosis process (Marchetti \& Wyrobek, 2008).

\subsubsection{Epigenetic Modifications}

Diazonin which was given orally has been reported to cause abortion of embryo which might involve an alteration in epigenetics of the sperm (Al-Saeed, 2016). Exposure towards Methamidophos in mice for 4 weeks orally affected rat's progeny by reducing the number of live foetuses, increasing number of dead and resorption foetus (Farag et al., 2012). Evidence-based on cohort and case study showed a type of herbicides Pentachlorophenol (PCP) increases susceptibility to developing lymphoma and leukaemia in exposed individual and children as result from paternal occupational exposure (Zheng et al., 2013). PCP is used widely in the wood preservation industry where wood treaters and sawmill workers were exposed to PCP in the work settings. Proper gene expression by male gamete is influenced by methylation and protein which control imprinting during development phase (Messerschmidt et al., 2014). Any error in epigenetic reprogramming during development may lead to abnormal cell fate in the early embryo as suggested although the exact is only recently beginning to be understood (Hales et al., 2011). Dimich-Ward et al. (1996) reported an increased risk of congenital malformations particularly in the eye and genital organs as well as anencephaly or spina bifida. Environmental or occupational exposure to pesticides causes an alteration in male germ line prior to conception, embryonic damage or feto-placental complex alterations. In addition, the residue of pesticides still exists in the seminal fluid of the father resulting from the toxins that build up in the body thus might defect sperm itself (Lacasaña et al., 2006). Polychlorinated biphenyl (PCB) was reported to impair DNA sperm integrity (Rignell-Hydbom et al., 2005). Hydroxylated PCB metabolites (OH-PCBs) might be one of the culprits of DNA damage in which other metabolite, quinones inhibit topoisomerase II activity, which plays an important role for sperm DNA remodelling (Sjodin et al., 2000; Srinivasan et al., 2002). To date, several dozen pesticides that associated with changes of male-mediated reproductive toxicity in animals and humans are summarised in Table 1 while Figure 1 shows mechanisms that might be involved.

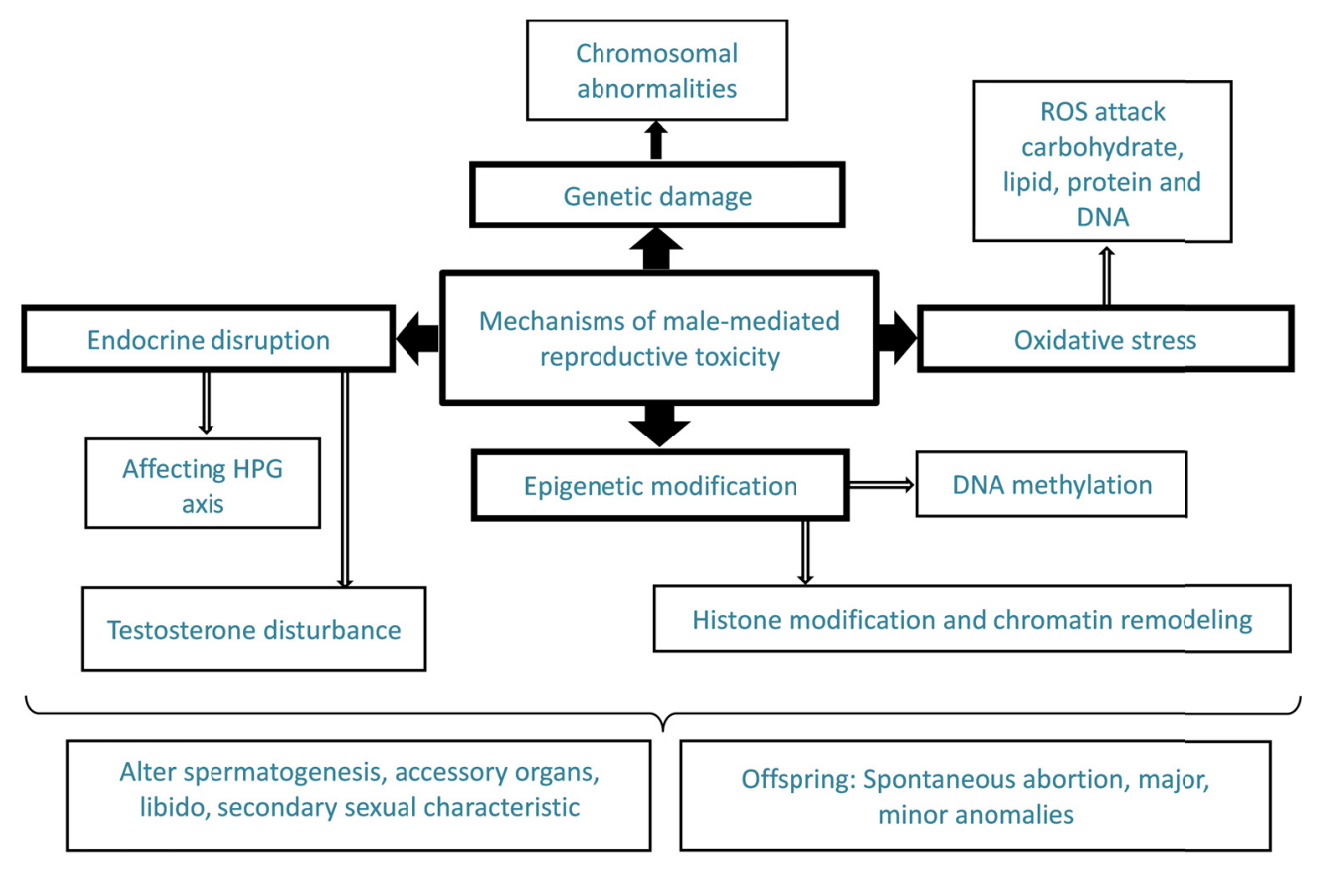

Figure 1. Summarisation of the mechanisms of male-mediated reproductive toxicity 
Table 1. Summary of common pesticides exposure associated with changes of male-mediated reproductive toxicity in animals and humans

\begin{tabular}{|c|c|c|c|c|c|c|}
\hline $\begin{array}{l}\text { Pesticides } \\
\text { Exposure }\end{array}$ & $\begin{array}{l}\text { Routes of } \\
\text { Exposure/ } \\
\text { Study } \\
\text { Design }\end{array}$ & $\begin{array}{l}\text { Dose } \\
(\mathrm{mg} / \mathrm{kg})\end{array}$ & $\begin{array}{l}\text { Duration } \\
\text { Time }\end{array}$ & $\begin{array}{l}\text { Animal/ } \\
\text { human }\end{array}$ & Outcomes & References \\
\hline Chlorpyrifos & Oral & $9.0 \mathrm{mg} / \mathrm{kg}$ & 70 days & Wistar rats & $\begin{array}{l}\downarrow \text { absolute and relative weight (prostate } \\
\text { gland, seminal vesicle), } \downarrow \text { motility, viability } \\
\& \uparrow \text { abnormal sperm morphology, } \Delta \text { testis } \\
\text { histology; } \downarrow \text { testosterone, } \downarrow \text { mating and } \\
\text { fertility indices }\end{array}$ & $\begin{array}{l}\text { El-Mazoudy } \\
\text { et al. (2011) }\end{array}$ \\
\hline Chlorpyrifos-ethyl & Oral & $\begin{array}{l}3.5,5.25 \\
10.5 \mathrm{mg} / \mathrm{kg}\end{array}$ & 90 days & Wistar rats & $\begin{array}{l}\downarrow \text { weights of organs, } \downarrow \text { motility \& sperm } \\
\text { count, } \Delta \text { testis histology abnormalities, } \\
\downarrow \text { fertility rate, } \downarrow \text { litter size, } \downarrow \text { viability rate, } \\
\downarrow \text { sex-ratio index }\end{array}$ & $\begin{array}{l}\text { Kenfack et al. } \\
(2015)\end{array}$ \\
\hline Chlorophenate & Cohort & - & 35 years & Male workers & $\begin{array}{l}\uparrow \text { risk of congenital anomalies of the eye, } \\
\text { (cataracts), } \uparrow \text { risks for developing } \\
\text { anencephaly or spina bifida, congenital } \\
\text { anomalies of genital organs }\end{array}$ & $\begin{array}{l}\text { Dimich-Ward } \\
\text { et al. (1996) }\end{array}$ \\
\hline Diazinon & Oral & $50 \mathrm{ml} / \mathrm{L}$ & 30 days & Wistar rats & $\begin{array}{l}\downarrow \text { body weight, } \downarrow \text { fertility rate, } \downarrow \text { mating } \\
\text { index, } \downarrow \text { number of litter size, abortion of } \\
\text { embryo, } \downarrow \text { semen volume, } \downarrow \text { motility \& } \\
\text { concentration, } \downarrow \text { sperm count, } \uparrow \text { abnormal } \\
\text { sperm, } \downarrow \text { testosterone level }\end{array}$ & $\begin{array}{l}\text { Al-Saeed } \\
(2016)\end{array}$ \\
\hline Dimethoate & Oral & $\begin{array}{l}0,3.66,5.50 \\
11 \mathrm{mg} / \mathrm{kg}\end{array}$ & 90 days & Wistar rats & $\begin{array}{l}\downarrow \text { relative weights of testes \& ventral } \\
\text { prostate, } \downarrow \text { sperm concentration, motility, } \\
\downarrow \text { level of protein, cholesterol \& activity of } \\
\text { prostatic acid phosphatase, } \downarrow \text { fertility, } \\
\text { gestation \& parturition indices, litter size, } \\
\text { the testicular histology of showed span of } \\
\text { Sertoli cells destruction \& disorganization } \\
\text { of the germinal epithelium. }\end{array}$ & $\begin{array}{l}\text { Ngoula et al. } \\
(2014)\end{array}$ \\
\hline Fenitrothion & Oral & $20 \mathrm{mg} / \mathrm{kg}$ & 28 days & Sprague-dawley & $\begin{array}{l}\downarrow \text { motility, count, maturation, viability } \\
\text { sperm, } \uparrow \text { sperm DNA damage }\end{array}$ & $\begin{array}{l}\text { Taib et al. } \\
(2014)\end{array}$ \\
\hline Imidacloprid & Oral & $\begin{array}{l}0.5,2,8 \\
\mathrm{mg} / \mathrm{kg}\end{array}$ & 90 days & Wistar rats & $\begin{array}{l}\downarrow \text { epididymis, vesicula seminalis, } \\
\text { epididymal, sperm concentration, body } \\
\text { weight gain, testosterone, glutathione, } \\
\uparrow \text { abnormal sperm, apoptosis, } \\
\text { fragmentation of sperm DNA }\end{array}$ & $\begin{array}{l}\text { Bal et al. } \\
(2012)\end{array}$ \\
\hline Malathion & Oral & $\begin{array}{l}0,250,500 \\
1000,2000 \\
\mathrm{mg} / \mathrm{kg}\end{array}$ & 12 days & $\begin{array}{l}\text { Swiss Webster } \\
\text { mice }\end{array}$ & $\begin{array}{l}\text { structural chromosome aberrations of } \\
\text { primary spermatocytes }\end{array}$ & $\begin{array}{l}\text { Salvadori et al. } \\
(1988)\end{array}$ \\
\hline Methamidophos & Oral & $\begin{array}{l}0,1,2,3 \\
\mathrm{mg} / \mathrm{kg}\end{array}$ & 4 weeks & Mice & $\begin{array}{l}\downarrow \text { number of live foetus, } \downarrow \text { number of dead } \\
\& \text { resorption foetus, } \uparrow \text { abnormal sperm } \\
\text { morphology, } \downarrow \text { sperm motility \& count, } \Delta \\
\text { brain, muscles, testes \& epididymis } \\
\text { abnormalities }\end{array}$ & $\begin{array}{l}\text { Farag et al. } \\
(2012)\end{array}$ \\
\hline Methomyl & Oral & $\begin{array}{ll}0.5 & 1.0 \\
\mathrm{mg} / \mathrm{kg} & \end{array}$ & 65 days & $\begin{array}{l}\text { Sprague- } \\
\text { dawley rats }\end{array}$ & $\begin{array}{l}\downarrow \text { fertility index, weight of testes and } \\
\text { accessory glands, } \downarrow \text { serum testosterone } \\
\text { level } \downarrow \text { sperm motility and count, } \uparrow \text { sperm } \\
\text { cell abnormality, } \uparrow \text { testicular lesions }\end{array}$ & $\begin{array}{l}\text { Shalaby et al. } \\
(2010)\end{array}$ \\
\hline Methyl-Parathion & i.p & $30 \mathrm{mg} / \mathrm{kg}$ & Single dose & Mice & $\begin{array}{l}\Delta \text { chromatin structure, } \uparrow \text { sperm DNA } \\
\text { damage, positive correlation between } \\
\text { MDA \& sperm DNA damage }\end{array}$ & $\begin{array}{l}\text { Piña-Guzmán } \\
\text { et al. (2006) }\end{array}$ \\
\hline Pentachlorophenol & $\begin{array}{l}\text { Cohort or } \\
\text { case-control }\end{array}$ & - & 2 generations & Male workers & $\begin{array}{l}\uparrow \text { risk of lymphoma \& leukemia in the } \\
\text { exposed individual and their children }\end{array}$ & $\begin{array}{l}\text { Zheng et al. } \\
(2013)\end{array}$ \\
\hline Pirimiphos-Methyl & Oral & $\begin{array}{l}41.67,62.5 \\
125 \mathrm{mg} / \mathrm{kg}\end{array}$ & 90 days & Wistar rats & $\begin{array}{l}\downarrow \text { absolute testis weight, seminal vesicle; } \\
\uparrow \text { relative testis weight, epididymis; } \downarrow \text { count, } \\
\text { sperm motility; } \uparrow \text { total protein, testis } \\
\text { cholesterol, } \downarrow \text { parturition indices \& pups } \\
\text { sex-ratio (M/F), enlargement of interstitial } \\
\text { space, inhibition of spermatogenesis, } \\
\text { rarefaction of leydig cells, edema in testes }\end{array}$ & $\begin{array}{l}\text { Ngoula et al. } \\
\text { (2014) }\end{array}$ \\
\hline $\begin{array}{l}\text { Polychlorinated } \\
\text { Biphenyls }\end{array}$ & Cohort & - & 12 years & Male workers & Impair sperm DNA integrity & $\begin{array}{l}\text { Rignell- } \\
\text { Hydbom } \\
\text { et al. (2005) }\end{array}$ \\
\hline
\end{tabular}




\section{Protective Measures by the Relevant Bodies and Users}

Inadequate concern was given to the effect of a product on the environment or consumer safety. Pesticide registration is a must to protect the client from spurious claims (WHO, 2010). Pesticide products must be labelled accordingly during registration process while implementing pesticide applicator training as well as certification. This is important to make sure that a license to purchase and use pesticide products labelled for restricted use can only be granted for trained applicators (Phung et al., 2012). Introduction of Pesticides Act 1974 is essential which regulates the labelling, registration, importation, manufacture, advertising, sale and storage of pesticides, controls the presence of pesticide residues in food while reporting and investigating of accidents and injuries caused by the pesticide. The act is implemented by Pesticides Board under the jurisdiction of the Ministry of Agriculture. Environmental Quality Act 1974 (Act 127) issued by Department of Environment play roles in controlling pesticide effluents from factories as well as Occupational Safety and Health Act 1994 (Act 514) that promote, stimulate and encourage high standards of safety and health of workers at work (Jiang, 2017). In addition, it is important to have personal protective equipment (PPE) such as chemical goggles, gloves, coveralls or apron, ear protection, respirator and frequently washing hands at work (Quandt et al., 2006). Besides, plastic caps and boots are recommended as they are waterproof and prevent absorption. Nowadays, users start to take supplements such as vitamin E in their diets. Previous studies have shown that vitamin E from palm oil tocotrienol-rich fraction and DL- $\alpha$-tocopherol acetate might have protective effect against treated rats by scavenging free radicals generated following pesticides exposures (Taib et al., 2014; Yassa et al., 2011).

\section{Conclusions}

Pesticide usage significantly increases from year to year, particularly in developing countries for food production, improving crop yields and the efficiency of food production processes, reducing the cost of food and providing high-quality products for consumers. The male germ line is quite sensitive to any toxic exposures as there is some evidence of male-mediated developmental toxicity in experimental models. As discussed here are few mechanisms suggested that might probably affecting males that later affecting their offspring such as epigenetic modification, genetic damage, endocrine dysfunction and oxidative stress. However, the exact role of male-mediated toxicity on such adverse effects like miscarriages and congenital malformations and how far damaged that comes from males could be passing through until the next generation offspring is not yet fully understood. Therefore, there is a need for inventive study designs especially aimed at studying paternal exposures and their roles from toxicants specifically towards male itself before mating with an unexposed female. The study of fertility and sexual behaviour should also be going beyond until later towards their offspring development.

\section{Acknowledgements}

The authors would like to thank the lecturers, researchers and staff of the Biomedical Science Programme, School of Diagnostic and Applied Health Sciences, Faculty of Health Sciences, Universiti Kebangsaan Malaysia and those who directly or indirectly supported this research. We also would like to acknowledge the financial support from Universiti Kebangsaan Malaysia via an internal grant (GGPM-2016-084).

\section{References}

Aaron, D., Goldberg, C., Allis, D., \& Bernstein, E. (2007). Epigenetics: A landscape takes shape. Cell, 28(4), 635-638.

Agarwal, A., Mulgund, A., Hamada, A., \& Chyatte, M. R. (2015). A unique view on male infertility around the globe. Reproductive Biology and Endocrinology, 13, 37. https://doi.org/10.1186/s12958-015-0032-1

Agarwal, A., Virk, G., Ong, C., \& du Plessis, S. S. (2014). Effect of oxidative stress on male reproduction. The World Journal of Men's Health, 32(1), 1-17. https://doi.org/10.5534/wjmh.2014.32.1.1

Albertini, D. F. (2014). Relevant and irrelevant translational discovery and male infertility: The case of the Y chromosome and more! Journal of Assisted Reproduction and Genetics, 31, 1113-1114. https://doi.org/ 10.1007/s10815-014-0325-x

Al-Saeed, M. H. (2016). Effect of grape seed oil on alterations of hematological parameters and semen fluid quality induced by diazinon in male rats. Asian Journal of Multidisciplinary Research, 2(6), 843-855.

Anderson, D., Schmid, T. E., \& Baumgartner, A. (2014). Male-mediated developmental toxicity. Asian Journal of Andrology, 16(1), 81-88. https://doi.org/10.4103/1008-682X.122342

Annabi, A., Dhouib, I. E., Dkhili, H., Bdiri, Y., Rejeb, I., Gharbi, N., ... Lasram, M. M. (2015). Mechanisms of imidacloprid-induced alteration of hypothalamic-pituitary-adrenal (HPA) axis after subchronic exposure in 
male rats. Recent Advances in Biology and Medicine, 1, 51-59. https://doi.org/10.18639/RABM. 2015.01.195931

Auyeung, B., Lombardo, M. V., \& Baron-Cohen, S. (2013). Prenatal and postnatal hormone effects on the human brain and cognition. Pflugers Archive: European Journal of Physiology, 465, 557-571. https://doi.org/ 10.1007/s00424-013-1268-2

Bal, R., Türk, G., Tuzcu, M., Yilmaz, O., Kuloglu, T., Gundogdu, R., ... Etem, E. (2012). Assessment of imidacloprid toxicity on reproductive organ system of adult male rats. Journal of Environmental Science and Health. Part. B, 47(5), 434-44. https://doi.org/10.1080/03601234.2012.663311

Bancroft, J. (2005). The endocrinology of sexual arousal. Journal of Endocrinology, 186, $411-427$. https://doi.org/10.1677/joe.1.06233

Bansal, A. K., \& Bilaspuri, G. S. (2011). Impacts of Oxidative stress and antioxidants on semen functions. Veterinary Medicine International, 2011, 686137. https://doi.org/10.4061/2011/686137

Birben, E., Sahiner, U. M., Sackesen, C., Erzurum, S., \& Kalayci, O. (2012). Oxidative stress and antioxidant defense. The World Allergy Organization Journal, 5(1), 9-19. https://doi.org/10.1097/WOX.0b013e3182 439613

Bonde, E. (2010). Semen analysis from an epidemiologic perspective. Asian Journal of Andrology, 12(1), 91-94. https://doi.org/10.1038/aja.2008.49

Bretveld, R. W., Thomas, C. M. G., Scheepers, P. T. J., Zielhuis, G. A., \& Roeleveld, N. (2006). Pesticide exposure: The hormonal function of the female reproductive system disrupted? Reproductive Biology and Endocrinology, 4, 30. https://doi.org/10.1186/1477-7827-4-30

Brugh, V. M., \& Lipshultz, L. I. (2004). Male factor infertility: Evaluation and management. Medical Clinics of North America, 88, 367-385. https://doi.org/10.1016/S0025-7125(03)00150-0

Carson, R. (1962). Silent Spring. Houghton Mifflin: Boston, MA, USA.

Chambers, J., \& Russell, L. C., Scott Boone, J., \& Howard, W. C. (2001). The metabolism of organophosphorus insecticides. Handbook of Pesticide Toxicology (pp. 919-927). https://doi.org/ 10.1016/B978-012426260-7.50048-3

Chen, J., Duan, C., \& Guan, Y. (2010). Sorptive extraction technique in sample preparation for organophosphorus pesticide in complex matrices. Journal of Chromatography B, 878, 1216-1225. https://doi.org/10.1016/j.jchromb.2010.02.031

Chen, J., Xiao, H. J., Qi, T., Chen, D. L., Long, H. M., \& Liu, S. H. (2015). Rare earths exposure and male infertility: The injury mechanism study of rare earths on male mice and human sperm. Environmental Science and Pollution Research, 22, 2076-2086. https://doi.org/10.1007/s11356-014-3499-y

Cheng, B. W., Guo, H., Li, Z. F., Ma, L., Wang, Y. L., Yang, L. J., ... Zheng, S. (2014). Identification of null and duplicated alleles for forensic DYS549, DYS527 and DYS459 in male infertility population. Y $i$ Chuan, 36, 786-792.

Cho, C., Jung-Ha, H., Willis, W. D., Goulding, E. H., Stein, P., Xu, Z., ... Eddy, E. M. (2003). Protamine 2 deficiency leads to sperm DNA damage and embryo death in mice. Biology of Reproduction, 69(1), 211-217. https://doi.org/10.1095/biolreprod.102.015115

Cho, C., William, W. D., Goulding, E. H., Jung-Ha, H., Choi, Y., Hecht, N. B., \& Eddy, E. M. (2001). Haploinsufficiency of protamine-1 or 2 causes infertility in mice. Nature Genetics, 28, 82-86. https://doi.org/10.1038/ng0501-82

Couse, J. F. (2008). Reproductive Toxicity. In R. C. Dlm Smart \& E. Hodgson (Eds.), Molecular and Biochemical Toxicology (4th ed., pp. 805-830). Singapore: Wiley. https://doi.org/10.1002/9780470285 251.ch33

D’Souza, U. J. A. (2017). Pesticide toxicity and oxidative stress: A review. Borneo Journal of Medical Sciences, 11(1), 9-19.

Das, P. P., Shaik, A. P., \& Jamil, K. (2007). Genotoxicity induced by pesticide mixtures: In-vitro studies on human peripheral blood lymphocytes. Toxicology and Industrial Health, 23(8), 449-58. https://doi.org/ $10.1177 / 0748233708089040$ 
Daxinger, L., \& Whitelaw, E. (2012). Understanding transgenerational epigenetic inheritance via the gametes in mammals. Nature Review Genetics, 13(3), 153-162. https://doi.org/10.1038/nrg3188

Dimich-Ward, H., Hertzman, C., Teschke, K., Hershler, R., Marion, S. A., Ostry, A., \& Kelly, S. (1996). Reproductive effects of paternal exposure to chlorophenate wood preservatives in the sawmill industry. Scandinavian Journal of Work, Environment and Health, 22, 267-273. https://doi.org/10.5271/sjweh.141

Eleršek, T., \& Filipič, M. (2011). Organophosphorus pesticides-mechanisms of their toxicity. Pesticides-The Impacts of Pesticides Exposure. InTech Europe: Croatia.

El-Mazoudy, R. H., Attia, A. A., \& Abd-El-Gawad, H. S. (2011). Evaluation of developmental toxicity induced by anticholinesterase insecticide, diazinon in female rats. Developmental and Reproductive Toxicology, 92(6), 534-542.

Farag, A. T., Radwan, A. H., Eweidah, M. H., El-Mazoudy, R. H., \& El-Sebae, A. E. (2012). Evaluation of male-mediated reproductive toxic effects of methamidophos in the mouse. Andrologia, 44(2), 116-124. https://doi.org/10.1111/j.1439-0272.2010.01113.x

Foster, P. M. D., \& Gray, J. L. E. (2008). Toxic responses of the reproductive system. In C. D. Klassen (Ed.), Casarett and Doull' Toxicology: The Basic Science of Poison (7th ed., pp. 761-806). McGrow-Hill, New York.

Gabrielsen, J. S., \& Tanrikut, C. (2016). Chronic exposures and male fertility: The impacts of environment, diet, and drug use on spermatogenesis. Andrology, 4(4), 648-661. https://doi.org/10.1111/andr.12198

Gava, M. M., Chagas, E. O., Bianco, B., Christofolini, D. M., Pompeo, A. C. L., Glina, S., \& Barbosa, C. P. (2011). Methylenetetrahydrofolate reductase polymorphisms are related to male infertility in Brazilian men. Genetic Testing and Molecular Biomarkers, 15(3), 153-157. https://doi.org/10.1089/gtmb.2010.0128

Geoffroy-Siraudin, C., Dieudonné Loundou, A., Romain, F., Achard, V., Courbière, B., Perrard, M. H., \& Guichaoua, M. R. (2012). Decline of semen quality among 10932 males consulting for couple infertility over a 20-year period in Marseille, France. Asian Journal of Andrology, 14(4), 584-59. https://doi.org/ 10.1038/aja.2011.173

Guerrero-Bosagna, C., Covert, T. R., Haque, M. M., Settles, M., Nilsson, E. E., Anway, M. D., \& Skinner, M. K. (2012). Epigenetic transgenerational inheritance of vinclozolin induced mouse adult onset disease and associated sperm epigenome biomarkers. Reproductive Toxicology, 34(4), 694-707. https://doi.org/10.1016/ j.reprotox.2012.09.005

Güneş, S., \& Kulaç, T. (2013). The role of epigenetics in spermatogenesis. Turkish Journal of Urology, 39(3), 181-187. https://doi.org/10.5152/tud.2013.037

Haimov-Kochman, R., Har-Nir, R., Ein-Mor, E., Ben-Shoshan, V., Greenfield, C., Eldar, I., ... Hurwitz, A. (2012). Is the quality of donated semen deteriorating? Findings from a 15 year longitudinal analysis of weekly sperm samples. The Israel Medical Association Journal, 14, 372-377.

Hales, B., Grenier, L., Lalancette, C., \& Robaire, B. (2011). Epigenetic programming: From gametes to blastocyst. Birth Defects Research. Part A, Clinical and Molecular Teratology, 91, 652-65. https://doi.org/ 10.1002/bdra.20781

Harton, G. L., \& Tempest, H. G. (2012). Chromosomal disorders and male infertility. Asian Journal of Andrologia, 14(1), 32-39. https://doi.org/10.1038/aja.2011.66

Hull, E. M., \& Dominguez, J. M. (2007). Seuxal behavior in male rodents. Hormones and Behavior, 52(1), 45-55. https://doi.org/10.1016/j.yhbeh.2007.03.030

Hunter, D., Anand-Ivell, R., Danner, S., \& Ivell, R. (2012). Models of in vitro spermatogenesis. Spermatogenesis, 2(1), 32-43. https://doi.org/10.4161/spmg.19383

Jiang, S. (2017). Overview of pesticide management in Malaysia. Retrieved November 10, 2017, from https://agrochemical.chemlinked.com/chempedia/overview-pesticide-managment-malaysia

Jin, B., Li, Y., \& Robertson, K. D. (2011). DNA methylation: superior or subordinate in the epigenetic hierarchy? Genes and Cancers, 2(6), 607-617. https://doi.org/10.1177/1947601910393957

Jones, P. A., \& Liang, G. (2009). Rethinking how DNA methylation patterns are maintained. Nature Reviews Genetics, 10, 805-811. https://doi.org/10.1038/nrg2651 
Kaneda, M., Okano, M., Hata, K., Sado, T., Tsujimoto, N., Li, E., \& Sasaki, H. (2004). Essential role for de novo DNA methyltransferase Dnmt3a in paternal and maternal imprinting. Nature, 429(6994), 900-903. https://doi.org/10.1038/nature02633

Katib, A. A., Al-Hawsawi, K., Motair, W., \& Bawa, A. M. (2014). Secondary infertility and the aging male, overview. Central European Journal of Urology, 67(2), 184-188. https://doi.org/10.5173/ceju.2014.02.art13

Kenfack, A., Ngoula, F., Dzeufiet, P. D. W., Ngouateu, O. B., Martine, T. M. A., Chombong, J. K., ... Vemo, N. B. (2015). Persistance of the reproductive toxicity of chlorphyrifos-ethyl in male Wistar rats. Asian Pacific Journal of Reproduction, 4(1), 37-40. https://doi.org/10.1016/S2305-0500(14)60055-5

Kim, K. H., Kabir, E., \& Jahan, S. A. (2017). Exposure to pesticides and the associated human health effects. The Science of Total Environment, 575, 525-535. https://doi.org/10.1016/j.scitotenv.2016.09.009

Kitamura, S., Sugihara, K., Fujimoto, N., \& Yamazaki, T. (2010). Organophosphate as endocrine disruptors. In T. Satoh \& R. C. Gupta (Eds.), Anticholinesterase Pesticides: Metabolism, Neurotoxicity \& Epidimiology (pp. 189-202). New Jersey, John Wiley \& Sons. Inc. https://doi.org/10.1155/2014/868303

Komiya, A., Kato, T., Kawauchi, Y., Watanabe, A., \& Fuse, H. (2014). Clinical factors associated with sperm DNA fragmentation in male patients with infertility. Scientific World Journal, 2014, 868303.

Lacasaña, M., Vázquez-Grameix, H., Borja-Aburto, V. H., Blanco-Muñoz, J., Romieu, I., \& Aguilar-Garduño, C. (2006). Maternal and paternal occupational exposure to agricultural work and the risk of anencephaly. Occupational and Environmental Medicine, 63(10), 649-656. https://doi.org/10.1136/oem.2005.023333

Lawrence, M., Daujat, S., \& Schneider, R. (2016). Lateral thinking: How histone modifications regulate gene expression, Trends in Genetic, 32(1), 42-56. https://doi.org/10.1016/j.tig.2015.10.007

Lestari, S. W., \& Rizki, M. D. (2016). Epigenetic: A new approach to etiology of infertility. Medical Journal of Indonesia, 24, 4.

Li, W., Wu, J., Kim, S. Y., Zhao, M., Hearn, S. A., Zhang, M. Q., \& Mills, A. A. (2014). Chd5orchestrates chromatin remodeling during sperm development. Nature Communications, 5, 3812.

Lukaszewicz-Hussain, A. (2010). Role of oxidative stress in organophosphate insecticide toxicity-Short review. Pesticide Biochemistry and Physiology, 98(2), 145-150. https://doi.org/10.1016/j.pestbp.2010.07.006

Maqbool, F., Mostafalou, S., Bahadar, H., \& Abdollahi, M. (2015). Review of endocrine disorders associated with environmental toxicants and possible involved mechanisms. Life Sciences, 145, $265-273$. https://doi.org/10.1016/j.lfs.2015.10.022

Marchetti, F., \& Wyrobek, A. J. (2008). DNA repair decline during mouse spermiogenesis results in the accumulation of heritable DNA damage. DNA Repair, 7, 572-581. https://doi.org/10.1016/j.dnarep. 2007.12.011

McGinnis, M. Y., \& Pfaff, D. W. (2012). Sexual Behaviors. Handbook of Neuroendocrinology (pp. 485-495). https://doi.org/10.1016/B978-0-12-375097-6.10020-4

Messerschmidt, D. M., Knowles, B. B., \& Solter, D. (2014). DNA methylation dynamics during epigenetic reprogramming in the germline and preimplantation embryos. Genes and Development, 28, 812-828. https://doi.org/10.1101/gad.234294.113

Mora-Esteves, C., \& Shin, D. (2013). Nutrient supplementation: Improving male fertility fourfold. Seminars in Reproductive Medicine, 31(4), 293-300. https://doi.org/10.1055/s-0033-1345277

Mostafalou, S., \& Abdollahi, M. (2013). Pesticides and human chronic diseases: Evidences, mechanisms, and perspectives. Toxicology and Applied Pharmacology, 268(2), 157-177. https://doi.org/10.1016/j.taap. 2013.01 .025

Ngoula, F., Watcho, P., Dongmo, M. C., Kenfack, A., Manga, J. N., Defang, H. F., ... Joseph, T. (2014). Effects of pirimiphos-methyl (an organophosphate insecticide) on the fertility of adult male rats. American Journal of Pharmacology and Toxicology, 7(1), 75-83. https://doi.org/10.3844/ajptsp.2014.75.83

Nobre, P. (2014). Male sexual dysfunctions. The Wiley Handbook of Cognitive Behavioral Therapy (1st ed.). John Wiley \& Sons, Ltd.

O’Donnell, L. (2014). Mechanisms of spermiogenesis and spermiation and how they are disturbed. Spermatogenesis, 4(2), e979623. https://doi.org/10.4161/21565562.2014.979623 
Phung, D. T., Connell, D., Miller, G., Rutherford, S., \& Chu, C. (2012). Pesticide regulations and farm worker safety: The need to improve pesticide regulations in Vietnam. Bulletin of the World Health Organization, 90 , 468-473. https://doi.org/10.2471/BLT.11.096578

Piña-Guzmána, B., Solís-Herediaa, M. J., Rojas-Garcíaab, A. E., Urióstegui-Acostaa, M., \& Quintanilla-Vegaa, B. (2006). Genetic damage caused by methyl-parathion in mouse spermatozoa is related to oxidative stress. Toxicology and Applied Pharmacology, 216(2), 216-224. https://doi.org/10.1016/j.taap.2006.05.001

Portela, A., \& Esteller, M. (2010). Epigenetic modifications and human disease. Nature Biotechnology, 28, 1057-1068. https://doi.org/10.1038/nbt.1685

Quandt, S. A., Hernandez-Valero, M. A., Grzywacz, J. G., Hovey, J. D., Gonzales, M., \& Arcury, T. A. (2006) Workplace, household, and personal predictors of pesticide exposure for farmworkers. Environmental Health Perspective, 114, 943-952. https://doi.org/10.1289/ehp.8529

Richter, K., Haslbeck, M., \& Buchner, J. (2010). The heat shock response: Life on the verge of death. Molecular Cell, 40, 253-66. https://doi.org/10.1016/j.molcel.2010.10.006

Rignell-Hydbom, A., Rylander, L., Giwercman, A., Jönsson, B. A. G., Lindh, C., Eleuteri, P., ... Hagmar, L. (2005). Exposure to PCBs and p,p'-DDE and human sperm chromatin integrity. Environmental Health Perspectives, 113(2), 175-179. https://doi.org/10.1289/ehp.7252

Rivera, R. M., \& Ross, J. W. (2013). Epigenetics in fertilization and preimplantation embryo development. Progress in Biophysics and Molecular Biology, 113(3), 423-32. https://doi.org/10.1016/j.pbiomolbio. 2013.02.001

Rousseaux, S., Reynoird, N., Escoffier, E., Thevenon, J., Caron, C., \& Khochbin, S. (2008). Epigenetic reprogramming of the male genome during gametogenesis and in the zygote. Reproductive BioMedicine Online, 16(4), 492-503. https://doi.org/10.1016/S1472-6483(10)60456-7

Sabeti, P., Pourmasumi, S., Rahiminia, T., Akyash, F., \& Talebi, A. R. (2016). Etiologies of sperm oxidative stress. International Journal of Reproductive Biomedicine, 14(4), 231-240.

Salvadoi, D. M., Eibeiro, L. R., Pereira, C. A., \& Becak, W. (1988). Cytogenetic effect of Malathion on somatic and germ cell of mice. Mutation Research, 204, 283-287. https://doi.org/10.1016/0165-1218(88)90101-2

Shalaby, M. A., El-Zorba, H. Y., \& Ziada, R. M. (2010). Reproductive toxicity of methomyl insecticide in male rats and protective effect of folic acid. Food and Chemical Toxicology, 48, 3221-3226. https://doi.org/ 10.1016/j.fct.2010.08.027

Shamsi, M. B., Kumar, K., \& Dada, R. (2011). Genetic and epigenetic factors: Role in male infertility. Indian Journal of Urology, 27(1), 110-120. https://doi.org/10.4103/0970-1591.78436

Sjodin, A., Hagmar, L., Klasson-Wehler, E., Bjork, J., \& Bergman, A. (2000). Influence of the consumption of fatty Baltic Sea fish on plasma levels of halogenated environmental contaminants in Latvian and Swedish men. Environmental Health Perspective, 108, 1035-1041. https://doi.org/10.1289/ehp.001081035

Srinivasan, A., Robertson, L. W., \& Ludewig, G. (2002). Sulfhydryl binding and topoisomerase inhibition by PCB metabolites. Chemical Research in Toxicology, 15, 497-505. https://doi.org/10.1021/tx010128+

Suratman, S., Edwards, S. W., \& Babina, K., (2015). Organophosphate pesticides exposure among farmworkers: Pathways and risk of adverse health effects. Review on Environmental Health, 30(1), 65-79.

Taib, I. S., Budin, S. B., Ghazali, A. R., Jayusman, P. A., \& Mohamed, J. (2014). Fenitrothion alters sperm characteristics in rats: Ameliorating effects of palm oil tocotrienol-rich fraction. Experimental Animal Journal, 63(4), 383-393. https://doi.org/10.1538/expanim.14-0016

Tamowski, S., Aston, K. I., \& Carrell, D. T. (2010). The use of transgenic mouse models in the study of male infertility. System Biology and Reproductive Medicine, 56(3), 260-273. https://doi.org/10.3109/19396368. 2010.485244

Tantibanchachai, C. (2014). Teratogens. Embryo Project Encyclopedia. Retrieved October 27, 2017, from http://embryo.asu.edu/handle/10776/7510

Tortora, G. J., \& Derrickson, B. H. (2012). The Endocrine System. Principles of Anatomy and Physiology (13th ed.). John Wiley \& Sons, Inc. 
Ucar, V. B., Nami, B., Acar, H., \& Kılınç, M. (2015). Is methylenetetrahydrofolate reductase (MTHFR) gene A1298C polymorphism related with varicocele risk? Andrologia, 47, 42-46. https://doi.org/10.1111/ and.12229

US Environmental Protection Agency. (1990). Guidelines for Developmental Toxicity Risk Assessment (pp. 63798-63826). Washington, DC: US Environmental Protection Agency.

Verma, K., \& Baniya, G. C. (2016). A comparative study of depression among infertile and fertile women. International Journal of Research in Medical Sciences, 4(8), 3459-3465. https://doi.org/10.18203/ 2320-6012.ijrms20162312

Vorvick, L., \& Storck, S. (2009). Miscarriage. Medline Plus Medical Encyclopedia. US National Library of Medicine and National Institutes of Health.

Wang, R. S., Yeh, S., Tzeng, C. R., \& Chang, C. (2009). Androgen receptor roles in spermatogenesis and fertility: Lessons from testicular cell-specific androgen receptor knockout mice. Endocrine Reviews, 30(2), 119-32. https://doi.org/10.1210/er.2008-0025

Watabe, T., Naka, S., Ikeda, H., Horitsugi, G., Kanai, Y., Isohashi, K., ... Hatazawa, J. (2014). Distribution of intravenously administered acetylcholinesterase inhibitor and acetylcholinesterase activity in the adrenal gland: 11c-donepezil PET study in the normal rat. PLoS One, 9(9), e107427. https://oi.org/10.1371/ journal.pone.0107427

Wolff, M., \& Woolard, P. (2011). Occupational and Environmental Exposures to the Newborn. Reproductive System. Retrieved October 15, 2017 from http:/www.iloencyclopaedia.org/part-i-47946/reproductivesystem/9/occupational-and-environmental-exposures-to-the-newborn

World Health Organization (WHO). (2010). International Code of Conduct on the Distribution and Use of Pes-ticides. Guidelines for the Registration of Pesticides. Rome: Italy.

World Health Organization (WHO). (2014). Sexual and reproductive health: Infertility is a global public health issue. Retrieved October 1, 2017, from http://www.who.int/reproductivehealth/topics/infertility/ perspective/en

Worthman, C. M. (2003). Energetics, Sociality, and Human Reproduction: Life History Theory in Real Life. National Research Council (US) Panel for the Workshop on the Biodemography of Fertility and Family Behavior. In K. W. Wachter \& R. A. Bulatao (Eds.), Offspring: Human Fertility Behavior in Biodemographic Perspective. Washington (DC): National Academies Press (US).

Yao, Z., Jiang, G., Liu, J., \& Cheng, W. (2001). Application of solid-phase microextraction for the determination of organophosphorous pesticides in aqueous samples by gas chromatography with flame photometric detector. Talanta, 55(4), 807-814. https://doi.org/10.1016/S0039-9140(01)00504-5

Yassa, V. F., Girgis, S. M., \& Abumourad, I. M. K. (2011). Potential protective effects of vitamin E on diazinon-induced DNA damage and some haematological and biochemical alterations in rats. Journal of Mediterranean Ecology, 11, 31-39.

Zarrouf, F. A., Artz, S., Griffith, J., Sirbu, C., \& Kommor, M. (2009). Testosterone and depression: Systematic review and meta-analysis. Journal of Psychiatric Practice, 15(4), 289-305. https://doi.org/10.1097/ 01.pra.0000358315.88931.fc

Zegers-Hochschild, F., Adamsom, G. D., Mouzon, J., Ishihara, O., Mansour, R., Nygren, K., ... Vanderpoel, S. (2009). The international committee for monitoring assisted reproductive technology (ICMART) and the world health organization (WHO) revised glossary on art terminology. Human Reproduction, 92(5), 1520-1524.

Zheng, R., Zhang, Q., Zhang Q., \& Yang, L. (2013). Occupational exposure to pentachlorophenol causing lymphoma and hematopoietic malignancy for two generations. Toxicology and Industrial Health, 31(4), 328-42. https://doi.org/10.1177/0748233712472520

Zoeller, R. T., Brown, T. R., Doan, L. L., Gore, A. C., Skakkebaek, N. E., Soto, A. M., ... Saal, F. S. (2012). Endocrine-disrupting chemicals and public health protection: A statement of principles from The Endocrine Society. Endocrinology, 153, 4097-4110. https://doi.org/10.1210/en.2012-1422 


\section{Copyrights}

Copyright for this article is retained by the author(s), with first publication rights granted to the journal.

This is an open-access article distributed under the terms and conditions of the Creative Commons Attribution license (http://creativecommons.org/licenses/by/4.0/). 